\title{
PENGGUNAAN MEDIA ALAM SEKITAR UNTUK MENINGKATKAN HASIL BELAJAR SISWA PADA PEMBELAJARAN IPA SEKOLAH DASAR
}

\author{
Sukristin $^{1}$, Abang Zainudin ${ }^{2}$ \\ ${ }^{1}$ Dosen STKIP Melawi (Kampus Entikong) \\ ${ }^{2}$ Mahasiswa STKIP Melawi Program Studi PGSD \\ Jln. Kuari Yayasan Lintas Batas Kecamatan Entikong Kabupaten Sanggau \\ Email : sukristintin@gmail.com,zainuddin_abang@yahoo.co.id
}

\begin{abstract}
The background of this research was the monotonous way in the process of science learning used by the teacher. The process of learning always did in the class room so that the student felt bored and gave negative effect to their final test. The aims of this research were to know how the steps of learning by media from environment, to increase the science learning outcome about the structure of plant, and to know the increasing of science learning outcome after using the media. This research used class action research method. The research did in two cycles that consisted of three meetings. The subject in this research was 23 students that consisted of 15 men and 8 women. The result of first cycle in the first meeting amounted the average 61,30 and the teacher teaching assessment amounted 2,20. The passing criteria of student in this meeting only amounted $39,1 \%$. In the second meeting, the average of learning outcome has increased to 75,40, but it did not reach yet the standard of the passing criteria. It was $68,9 \%$. Then, the teacher teaching assessment in good enough category, in average 3. In the third meeting, the average of student learning outcome increased to 87,83 with the passing criteria amounted $95,7 \%$. The teacher teaching assessment amounted 3,75 in good category.
\end{abstract}

Key Words: Student learning outcome, Media from environment.

\begin{abstract}
Abstrak: Latar belakang penelitian ini adalah sering dijumpai dalam pembelajaran Ilmu Pengetahuan alam guru terlalu monoton dalam melaksanakan pembelajaran. Pelaksanaan yang dilakukan terfokus didalam kelas sehingga siswa menjadi jenuh dalam mengikuti pelajaran, sehingga hasil ulanganya rendah. Tujuan penelitian ini adalah untuk mengetahui langkah-langkah pembelajaran dengan mengunakan media alam sekitar, untuk meningkatkan hasil belajar siswa tentang materi bagian struktur tumbuh-tumbuhan, serta untuk mengetahui sejauhmanakah peningkatan hasil belajar siswa dalam pembelajaran IPA tentang struktur bagian tumbuh-tumbuhan setelah mengunakan media lingkunagan sekiatar. Metode penelitian ini dengan menggunakan Penelitian Tindakan Kelas (PTK). Penelitian ini dilaksanakan dalam satu siklus yang terdiri dari 3 kali pertemuan, dengan jumlah subjek siswa sebanyak 23 orang yang terdiri dari 15
\end{abstract}


orang laki-laki dan 8 orang perempuan. Hasil belajar Siswa pada siklus 1 Pertemuan pertama nilai rata yang dipelroleh adalah 61,30 dan hasil pengamatan guru mengajar adalah 2,20, untuk kreteria keberhasilan siswa pada pertemuan satu ini baru mencapai $39,1 \%$, pada peretmuan kedua rata-rata hasil belajar siswa sudah ada peningkatann yaitu menjadi 75,40 namun kreteria keberhasilan belum memnuhi standar yang ditentukan karena baru mencapai 68,9\%, sedang hasil pengamatan guru mengajar baru mencapai kategori cukup baik yaitu ratanya 3, selanjutnya pertemua ke 3 rata-rata hasil belajar siswa meningkat menjadi 87,83 dengan kreteria keberhasilan $95,7 \%$, dan hasil rata-rata pengamatan guru mengajar adalah 3,75 dengan kategori baik. Pengunaan media alam sekitar secara langsung dengan disertai metode yang tepat pada pembelajaran struktur bagian tumbuh-tumbuhan, dapat menigkatkan hasil belajar siswa, terbukti dari setiap pertemuan hasil belajar siswa mengalami suatu peningkatan.

Kata Kunci: Hasil Belajar meningkat, Media Lingkungan Alam Sekitar.

Warakteristik siswa sekolah dasar ingin tahu, dan belajar dengan sesuatu yang nyata. Selain itu, gaya belajar antara murid satu dan lainnya juga pasti berbeda. Dalam hal ini peranan guru sangat penting untuk mampu memenuhi kebutuhan siswa agar mereka lebih banyak mengetahui halhal yang nyata ditemuinya dalam kehidupan sehari-hari. Di dalam KTSP (2007:220) mengatakan bahwa untuk pembelajaran sains yang menjadi fokus dalam pembelajaran adalah adanya interaksi antara siswa dengan obyek atau alam secara langsung.

Mata pelajaran Ilmu Pengetahuan Alam memberikan ilmu tentang alam yang sering dijumpai siswa dalam keidupan sehari-hari, akan tetapi tidak banyak siswa yang menyadari bahwa apa yang dilakukan dan dijumpai secara langsung merupakan ilmu tentang alam. Akibatnya mereka tidak bisa menerapkannya dalam mata pelajaran yang diberikan oleh guru di kelas.

Permasalahan tersebut sering dijumpai dalam pembelajaran Ilmu Pengetahuan Alam karena guru terlalu monoton dalam melaksanakan pembelajaran. Pelaksanaan yang dilakukan terfokus di dalam kelas sehingga siswa menjadi jenuh dalam mengikuti pelajaran. Media pembelajaran merupakan alat bantu atau perantara dalam menyampaikan informasi pengetahuan. Semakin konkret siswa mempelajari bahan 
pengajaran, maka semakin banyaklah pengalaman yang diperoleh murid.

Kekurangan peneliti sebagai guru dalam melaksanakan pembelajaran bagian tumbuhan di kelas IV Sekolah Dasar adalah guru jarang menggunakan metode pembelajaran yang variatif, selalu menggunakan metode ceramah dalam melaksanakan pembelajaran. Guru tidak pernah menggunakan Rencana Pelaksanaan Pembelajaran dalam melaksanakan pembelajaran. Guru tidak dapat mengaktifkan suasana belajar dalam menyampaikan materi bagian-bagian tumbuhan, Guru hanya menggunakan satu buku penunjang dalam menyampaikan materi, Guru tidak pernah menggunakan metode penggunaan media alam sekitar dalam pembelajaran mengenal Struktur bagian-bagian pada tumbuhan. Dampak dari kebiasaan guru dalam melaksanakan pembelajaran yang monoton pada materi Struktur bagianbagian tumbuhan mengakibatkan siswa kurang memahami konsep tentang bagian-bagian tumbuhan sehingga sering melakukan kesalahan dalam menjawab soal yang diberikan sehinnga hasil ulangan harian siwa sangatlah kurang.
Berdasarkan hasil diagnosis kesalahan yang guru dan lakukan dengan menggunakan soal evaluasi, terdapat kesalahan dalam siswa menjawab soal yang diberikan. Contohnya sebagai berikut:

Pertanyaan : Sebutkan bagian-bagian tumbuhan!

Hasil jawaban : Pohon pisang, bunga, pohon sawit, mangga dan jambu

Hasil jawaban dari siswa tidak memuaskan, hal ini di sebabkan siswa kurang memahami bagian-bagian dari tumbuhan.

Akibat dari jawaban siswa tentang bagian-bagian dari tumbuhan, maka nilai ulangan siswa menjadi rendah. Adapun nilai ulangan harian pada materi struktur bagian-bagian dari tumbuhan adalah rata-rata 58,70, masih dibawah Kriteria Ketuntasan Minimum yang guru tetapkan yaitu mencapai minimal rata-rata 70 atau adanya suatu kenaikan yang signifikan untuk siwa yaitu minimal $70 \%$ dari siswa sudah mencapai nilai 70 , sesuai yang ditetapkan untuk mata pelajaran Ilmu Pengetahuan Alam di kelas IV Sekolah Dasar Negeri 16 Mobui. 
Tabel 1. Hasil belajar siswa pada ulangan harian materi struktur dan bagian tumbuhtumbuhan

\begin{tabular}{lll}
\hline Nomor & \multicolumn{1}{c}{ Nama Siswa } & Hasil ulangan harian siswa \\
\hline 1 & Ayang Rehat & 65 \\
2 & Romanus & 40 \\
3 & Yoga Saputra & 40 \\
4 & Yohanes Kaka & 70 \\
5 & Yunita & 50 \\
6 & Zakaria Raka & 40 \\
7 & Markus & 50 \\
8 & Yulius & 45 \\
9 & Andreas Tresno & 70 \\
10 & Damai Humiroh & 65 \\
11 & Dainum & 70 \\
12 & Desni & 55 \\
13 & Ferdi & 85 \\
14 & Johana Ester & 35 \\
15 & Yulia Herlena & 35 \\
16 & Gibran & 45 \\
17 & Martila & 50 \\
18 & Melpin & 85 \\
19 & Deo & 85 \\
20 & Paulus Andika & 75 \\
21 & Pengki & 75 \\
22 & Ahyen & 50 \\
23 & Roman & 70 \\
\hline Jumlah & & 1.350 \\
\hline Rata-rata & & 58,70 \\
\hline
\end{tabular}

Untuk mengatasi permasalahan mengajar guru dan juga mengatasi kesulitan belajar siswa pada pembelajaran Ilmu Pengetahuan Alam khususnya materi struktur bagianbagian dari tumbuhan, maka peneliti menggunakan media alam sekitar karena dengan menggunakan media alam sekitar pada pembelajaran mengenal bagian tumbuhan, siswa berhubungan langsung dengan objek yang hendak dipelajari, sehingga dapat memahami bagian-bagian dari tumbuhan. Selain itu, dengan penggunaan media alam sekitar, maka ada kecenderungan ilmu yang diperoleh siswa menjadi kongkrit sehingga akan memperoleh hasil belajar yang tingg. Oleh sebab itu, peneliti mencoba untuk menggunakan media alam sekitar dalam melakukan Penelitian Tindakan Kelas di kelas IV Dasar Negeri 16 Mobui Kecamatan Kembayan, dengan judul “ Pengunaan media Alam sekitar untuk meningkatkan Hasil Belajar Siswa Dalam IPA Sekolah Dasar”.

Berdasarkan rumusan masalah yang sudah penulis paparkan di atas maka tujuan dari penelitian ini adalah mengetahui langkah-langkah persiapan pembelajaran dengan menggunakan media alam sekitar dalam meningkatkan hasil belajar siswa tentang struktur bagian-bagian tumbuhan. Selain itu, untuk 
mengetahui sejauh manakah peningkatan hasil belajar siswa tentang struktur bagian-bagian tumbuhan setelah pembelajaran menggunakan media lingkungan alam sekitar.

Hasil belajar merupakan bagian terpenting dalam pembelajaran. Nana Sudjana (2009:3) mendefinisikan hasil belajar siswa pada hakikatnya adalah perubahan tingkah laku sebagai hasil belajar dalam pengertian yang lebih luas mencakup bidang kognitif, afektif, dan psikomotorik. Dimyati dan Mudjiono (2006: 3-4) juga menyebutkan hasil belajar merupakan hasil dari suatu interaksi tindak belajar dan tindak mengajar. Dari sisi guru, tindak mengajar diakhiri dengan proses evaluasi hasil belajar. Dari sisi siswa, hasil belajar merupakan berakhirnya pengajaran dari puncak proses belajar. Bloom dalam Dimyati dan Mudjiono,

(2006:26-27) menyebutkan enam jenis perilaku ranah kognitif, sebagai berikut:

1) Pengetahuan, mencapai kemampuan ingatan tentang hal yang telah dipelajari dan tersimpan dalam ingatan. Pengetahuan itu berkenaan dengan fakta, peristiwa, pengertian kaidah, teori, prinsip, atau metode.
2) Pemahaman, mencakup kemampuan menangkap arti dan makna tentang hal yang dipelajari.

3) Penerapan, mencakup kemampuan menerapkan metode dan kaidah untuk menghadapi masalah yang nyata dan baru. Misalnya, menggunakan prinsip.

4) Analisis, mencakup kemampuan merinci suatu kesatuan ke dalam bagian-bagian sehingga struktur keseluruhan dapat dipahami dengan baik. Misalnya mengurangi masalah menjadi bagian yang telah kecil.

5) Sintesis, mencakup kemampuan membentuk suatu pola baru. Misalnya kemampuan menyusun suatu program

6) Evaluasi, mencakup kemampuan membentuk pendapat tentang beberapa hal berdasarkan kriteria tertentu. misalnya, kemampuan menilai hasil ulangan.

\section{METODELOGI PENELITIAN}

Penelitian ini menggunakan penelitian tindakan kelas (Classroom Action Research). Arikunto (2010) mengatakan bahwa penelitian tindakan kelas merupakan suatu pencermatan terhadap kegiatan belajar berupa sebuah tindakan, yang sengaja dimunculkan dan terjadi dalam sebuah 
kelas secara bersama.tindakan tersebut diberikan oleh guru atau dengan arahan dari guru yang dari guru yang dilakukan oleh siswa. Jenis penelitian yang dipakai untuk masalah ini adalah "Penelitian Tindakan Kelas Kolaboratif" karena penelitian ini melibatkan guru, peneliti dan berbagai pihak yang terkait secara bersama sama untuk mencari penyelesaian terhadap masalah tersebut.

Dalam penelitian ini, peneliti bermaksud mengungkapkan faktafakta yang ada pada saat penelitian dilakukan. Jadi peneliti menggunakan metode deskriptif. (Classroom Action Research). Menurut Arikunto (2010) penelitian tindakan kelas penelitian yang ditujukan untuk menggambarkan fenomena-fenomena yang ada, berlangsung pada saat ini atau saat yang lampau". Penelitian deskriptif, bisa mendesripsikan suatu keadaan saja, tetapi bisa juga mendeskripsikan keadaan dalam tahapan-tahapan perkembangannya. Penelitian ini tidak mengadakan manipulasi atau pengubahan pada variable-variabel bebas, tetapi menggambarkan suatu kondisi apa adanya.

\section{HASIL DAN PEMBAHASAN}

\section{Hasil Penelitian Siklus 1}

Dalam penelitian ini, peneliti menggunakan satu siklus, yang terdiri atas 3 kali pertemuan.

Pada siklus ini dilaksanakan pada tanggal 30 April 2018, 01 Mei 2018 dan 07 Mei 2018 di kelas IV Sekolah Dasar Negari 16 Mobui kecamatan Kembayan. Pada penelitian tersebut terdiri dari 23 orang siswa yang terdiri dari 15 orang siswa lakilaki dan 8 orang siswa perempuan. Untuk masing-masing pertemuan memerlukan waktu 2 X 35 menit. Kegiatan pembelajaran dilakukan oleh peneliti sendiri dan dibantu oleh seorang teman sejawat sebagai observer.

\section{Pertemuan 1}

Kegiatan pembelajaran pada pertemuan pertama dilakukan oleh guru yaitu pertama-tama mengucapkan salam dan berdoa selanjutnya mengecek kehadiran siswa yaitu dengan cara mengabsen satu persatu. Guru mengungkapkan konsep awal tentang pembelajran materi bagian tumbuh-tumbuhan yang dikaitkan dengan alam sekitar, juga menyampaikan tujuan pembelajran tentang materi yang akan dipelajari, 
selanjutnya guru menyampaikan materi tentang struktur tumbuhtumbuhan serta mengamati respon siswa terhadap materi yang akan disampaikan. Model belajar adalah model pembelajaran yang menggunakan sistem kelompok, dimana dalam satu kelompok terdiri dari 4 - 5 orang siswa. Pada masingmasing kelompok terdiri dari siswa yang mempunyai kemampuan heterogen. Artinya dalam satu kelompok ada siswa yang pintar, sedang dan juga kurang. Guru mencoba memberikan LKS yang berupa soal jawaban singkat yang

Tabel 2. Hasil observasi guru mengajar Pertemuan Pertama

\begin{tabular}{|c|c|c|c|c|c|}
\hline \multirow{2}{*}{ NO } & \multirow[t]{2}{*}{ Aspek Yang Dinilai } & \multicolumn{4}{|c|}{ Kemunculan } \\
\hline & & 1 & 2 & 3 & 4 \\
\hline 1. & Apersepsi/motivasi & & $\sqrt{ }$ & & \\
\hline 2. & Tehnik pembagian kelompok & & $\sqrt{ }$ & & \\
\hline 3. & Menjelaskan tugas kelompok & & $\sqrt{ }$ & & \\
\hline 4. & Menjelaskan materi diskusi & & $\sqrt{ }$ & & \\
\hline 5. & Pengelolaan materi diskusi & & $\sqrt{ }$ & & \\
\hline 6. & $\begin{array}{l}\text { Memberi bimbingan saat siswa melakukan diskusi } \\
\text { kelompok, bagi kelompok yang bermasalah }\end{array}$ & & $\sqrt{ }$ & & \\
\hline 7. & $\begin{array}{l}\text { Menunjuk siswa yang sudah } \text { selesai untuk } \\
\text { mempresentasikan ke depan }\end{array}$ & & & $\sqrt{ }$ & \\
\hline 8. & Menjelaskan secara singkat tentang hasil diskusi & & $\sqrt{ }$ & & \\
\hline 9. & $\begin{array}{l}\text { Bersama siswa membuat kesimpulan tentang materi yang } \\
\text { telah didiskusikan }\end{array}$ & & & $\sqrt{ }$ & \\
\hline 10. & Menutup pembelajaran & & $\sqrt{ }$ & & \\
\hline Jumlah & & 22 & & & \\
\hline \multirow{2}{*}{$\begin{array}{l}\text { Rata- } \\
\text { rata }\end{array}$} & 22 & 2,2 & & & \\
\hline & 10 & & & & \\
\hline
\end{tabular}

Guru telah melakukan tahapantahapan pembelajaran dengan kategori tidak baik, hal ini dapat dilihat dari perolehan skor rata-rata yaitu 2,2 (tidak baik). Masih banyak siswa yang kurang aktif dalam tugas kelompok. Ini tentunya karena siswa masih dalam penyesuian dengan anggota 


$\begin{array}{lcccc}\begin{array}{l}\text { kelompoknya, } \\ \text { memanggil seniliti }\end{array} \text { tidak } & \text { Hasil kerja siswa pada materi } \\ \text { perwakilan dari kelompok, untuk } & \text { satu } & \text { siswa } & \text { struktur tumbuh-tumbuhan mengenai } \\ \text { mempresentasikan hasil } & \text { kerja } & \text { siklus satu yang di mana guru dalam } \\ \text { kelompoknya, dan guru tiadak } & \text { melakukan pembelajran yang masih } \\ \text { melaksanakan tahapan tahapan } & \text { banyak langkah-langkah pembelajaran } \\ \text { pembelajaran dengan mengunakan } & \text { dengan mengunakan media alam } \\ \text { media alam sekitar dengan baik. } & \text { sekitar yang banyak yang belum }\end{array}$

Tabel 3. Hasil Kerja Siswa Siklus I Pertemuan Pertama

\begin{tabular}{llc}
\hline Nomor & Nama Siswa & Hasil ulangan harian siswa \\
\hline 1 & Ayang Rehat & 65 \\
2 & Romanus & 50 \\
3 & Yoga Saputra & 50 \\
4 & Yohanes Kaka & 70 \\
5 & Yunita & 50 \\
6 & Zakaria Raka & 50 \\
7 & Markus & 50 \\
8 & Yulius & 45 \\
9 & Andreas Tresno & 70 \\
10 & Damey Humiroh & 65 \\
11 & Denu & 65 \\
12 & Desni & 55 \\
13 & Ferdi & 75 \\
14 & Juana Ester & 40 \\
15 & Yulia Helena & 45 \\
16 & Gibran & 50 \\
17 & Martila & 55 \\
18 & Melpin & 85 \\
19 & Deo & 80 \\
20 & Paulus Andika & 80 \\
21 & Pengki & 75 \\
22 & Ahyen & 55 \\
23 & Roman & 75 \\
\hline Jumlah & & 1410 \\
\hline Rata-rata & & 61,30 \\
\hline
\end{tabular}

Pada pertemuan pertama guru disadari sepenuhnya oleh peneliti hanya memberikan sebagian materi karena waktu yang terbatas. Selain itu tentang struktur tumbuh-tumbuhan peneliti juga tidak dapat memberikan sebatas daun, guru tidak sempat bimbingan secara merata kepada siswa memberikan kuis pada akhir pelajaran yang kelompoknya kurang bisa karena keterbatasan waktu. Hal ini mengerjakan soal. 
Kriteria yang ditetapkan peneliti dalam penelitian ini adalah minimal rara-rata nilai yang diperoleh adalah 70, sedangkan skor rata-rata hasil observasi hasil belajar siswa dalam pertemuan pertama ini hanya 61,30 jadi siswa dalam belajar tentang materi struktur tumbuh-tumbuhan bagian daun belum mengunakan media alam sekitar secara langsung, masih belum mencapai kreteria yang peneliti tetapkan yaitu rata-ratanya sebesar 70, dan yang mendapatkan nilai $\geq 70$ baru mencapai $39,1 \%$.

Nilai perkembangan individu belum dapat dilihat, karena untuk evaluasi siklus 1 pertemuan pertama dilakukan setelah selesai pertemuan 3 pada siklus 1, setelah guru memberikan pembelajaran dengan mengunakan media alam sekitar secara langsung.

\section{Pertemuan 2}

Kegiatan pembelajaran kedua dilakukan peneliti seperti pembelajaran pertama yaitu memberi salam, berdoa melakukan abversensi, memberi motivasi. Peneliti juga mengingatkan kepaada siswa pelajaran yang lalu. Peneliti dalam pertemuan kedua ini menjelaskan materi selanjutnya yang dalam pertemuan pertama belum dibahas yaitu tentang batang, namun belum mengunakan media alam sekitar secaralangsung karena keterbatasan waktu. Peneliti memberikan bimbingan kepada siswa dalam kerja kelompok, kemudian siswa mendiskusikan tentang pembelajaran struktur tumbuhan bagian batang.

Guru mengamati keaktifan siswa dalam kegiatan belajar dan selanjutnya siswa dipersilahkan guru untuk bertanya dan guru menangapi pertanyaan pertanyaan dari siswa tersebut, selanjutnay guru meminta siswa untuk melakukan presntasi dari hasil didkusi,Lalu peneliti mengamati keaktifan siswa dalam melakukan presentasi, kemudian guru melakukan kuis yang diberiakan kepada setiap kelompok, kemudianmembagikan LKS 2 untuk dipahami dan dikerjakan oleh siswa secara individu namun didiskusikan terlebih dahulu dengan kelompoknya.

Hasil pengamatan yang dilakukan teman sejawat dalam siklus satu pertemuan kedua setelah guru melakukan perbaikan pembelajarn, dalam pertemuan kedua banyak langkah-langkah yang belum peneliti lakukun, hasil observasi dapat dilihat dalam tabel hasil observasi guru mengajar (tabel 4) 
Tabel 4. Hasil Observasi Guru Mengajar Pada Pertemuan Kedua

\begin{tabular}{|c|c|c|c|c|c|}
\hline \multirow{2}{*}{ NO } & \multirow[b]{2}{*}{ Aspek Yang Dinilai } & \multicolumn{4}{|c|}{ kemunculan } \\
\hline & & 1 & 2 & 3 & 4 \\
\hline 1. & Apersepsi/motivasi & & & $\sqrt{ }$ & \\
\hline 2. & Tehnik pembagian kelompok & & & $\sqrt{ }$ & \\
\hline 3. & Menjelaskan tugas kelompok & & $\sqrt{ }$ & & \\
\hline 4. & Menjelaskan materi diskusi & & & $\sqrt{ }$ & \\
\hline 5. & Pengelolaan materi diskusi & & & $\sqrt{ }$ & \\
\hline 6. & $\begin{array}{l}\text { Memberi bimbingan saat siswa melakukan diskusi } \\
\text { kelompok, bagi kelompok yang bermasalah }\end{array}$ & & & $\sqrt{ }$ & \\
\hline 7. & $\begin{array}{l}\text { Menunjuk siswa yang sudah selesai untuk } \\
\text { mempresentasikan ke depan }\end{array}$ & & & $\sqrt{ }$ & \\
\hline 8. & Menjelaskan secara singkat tentang hasil diskusi & & & $\sqrt{ }$ & \\
\hline 9. & $\begin{array}{l}\text { Bersama siswa membuat kesimpulan tentang materi } \\
\text { yang telah didiskusikan }\end{array}$ & & & $\sqrt{ }$ & \\
\hline 10. & Menutup pembelajaran & & & & $\sqrt{ }$ \\
\hline Jumlah & & 20 & & & \\
\hline \multirow[t]{2}{*}{ Rata-rata } & 30 & 3 & & & \\
\hline & 10 & & & & \\
\hline
\end{tabular}

Tabel 5. Hasil kerja siswa pada pertemuan kedua

\begin{tabular}{llc}
\hline Nomor & Nama Siswa & Hasil ulangan harian siswa \\
\hline 1 & Ayang Rehat & 90 \\
2 & Romanus & 75 \\
3 & Yoga Saputra & 65 \\
4 & Yohanes Kaka & 80 \\
5 & Yunita & 70 \\
6 & Zakaria Raka & 55 \\
7 & Markus & 60 \\
8 & Yulius & 70 \\
9 & Andreas Tresno & 75 \\
10 & Damey & 90 \\
& Humiroh & \\
11 & Denu & 95 \\
12 & Desni & 65 \\
13 & Ferdi & 100 \\
14 & Juana Ester & 55 \\
15 & Yulia Herlena & 50 \\
16 & Gibran & 65 \\
17 & Martila & 65 \\
18 & Melpin & 100 \\
19 & Deo & 95 \\
20 & Paulus Andika & 85 \\
21 & Pengki & 90 \\
22 & Ahyen & 65 \\
23 & Roman & 75 \\
\hline Jumlah & & 1.735 \\
\hline Rata-rata & & 75,4 \\
\hline & &
\end{tabular}

Keterangan :

$\begin{array}{llll}\text { 1. Sangat tidak baik } & : 1 & \text { 3. Cukup baik } & : 3 \\ \text { 2. Kurang baik } & : 2 & \text { 4. Baik } & : 4\end{array}$


Dalam pertemuan kedua, guru sudah cukup baik dalam mengajar karena sudah melaksanakan langkahlangkah pembelajaran dengan baik, dimana skor untuk guru adalah 3 (cukup baik). Dalam siklus 1 pertemuan 2 guru sudah dapat mengelola waktu dengan baik, sehingga guru dapat memberikan kuis terlebih dahulu sebelum memberikan LKS. Sudah terdapat beberapa siswa yang dapat menyelesaikan tugasnya dengan cepat dan betul banyak yang mencapai nilai di atas ketentuan yang peneliti terapkan, berikut ini adalah hasil kerja siswa pada pertemuan ke dua.

Skor rata-rata observasi untuk siswa pada pertemuan 2 pada siklus 1 adalah 75,4, dilihat dari rata-rata hasil evaluasi siswa sudah mencapai nilai rata-rata yang ditentukan penelitiyaitu 70 , tetapi apabla dilihat dari prosentsi keberhasilan siswa baru mencapai $68,9 \%$ dari siswa yang mendapatkan nilai $\geq 70$.

Pembelajaran sudah cukup baik, artinya setiap anggota kelompok sudah dapat bekerja sama dengan kelompoknya masing-masing. Akan tetapi masih terdapat juga beberapa dari mereka yang mengerjakan tugas kelompok secara individu. Nilai perkembangan ini dapat dilihat dari nilai menjawab kuis. Selanjutnya guru memberikan PR. Kepada setiap kelompok.

\section{Pertemuan 3}

Pada pertemuan 3 peneliti melakukan seperti yang dilakukan pada pertemuan sebelumnya yaitu memberi salam, berdoa, serta melakukan abversensi, selanjutnaya guru membahas PR yang telah diberikan pada pertemuan sebelumnya, siswa diminta untuk mempresentasikan hasil pekerjaan rumahnya sesuai dengan kelompoknya masing-masing, berikutnya guru mengulas materi yang sebelumya diberikan, selnjutnya guru mengajak siswa untuk melakukan pengamatan langsung dengan mengunakan media alam sekitar mengenai materi struktur tumbuhtumbuhan yaitu bagian akar, guru membimbing dan mengarahkan siswa dalam setiap kelompok.

Guru meminta siswa untuk mempresentasikan hasil kerja kelompok diberikan secara adil. Artinya kelompok yang belum pernah mempresentasikan hasil kelompok ke depaan diberi kesempatan untuk mempresentasikan dan setiap 


$\begin{array}{lccl}\text { kelompok } & \text { diberikan } & \text { untuk } & \text { siswa yang diberikan kuis, mereka } \\ \text { menyimpulkan } & \text { dari } & \text { hasil } & \text { sangat atusias dan mereka semua aktif } \\ \text { pengamatan.Guru } & \text { memberikan } & \text { kuis } & \text { dalam menjawabnya. }\end{array}$
dari hasil pengamatan siswa melalui media alam sekitar. Dilihat dari respon

Tabel 6. Hasil observasi guru mengajar pada pertemuan 3

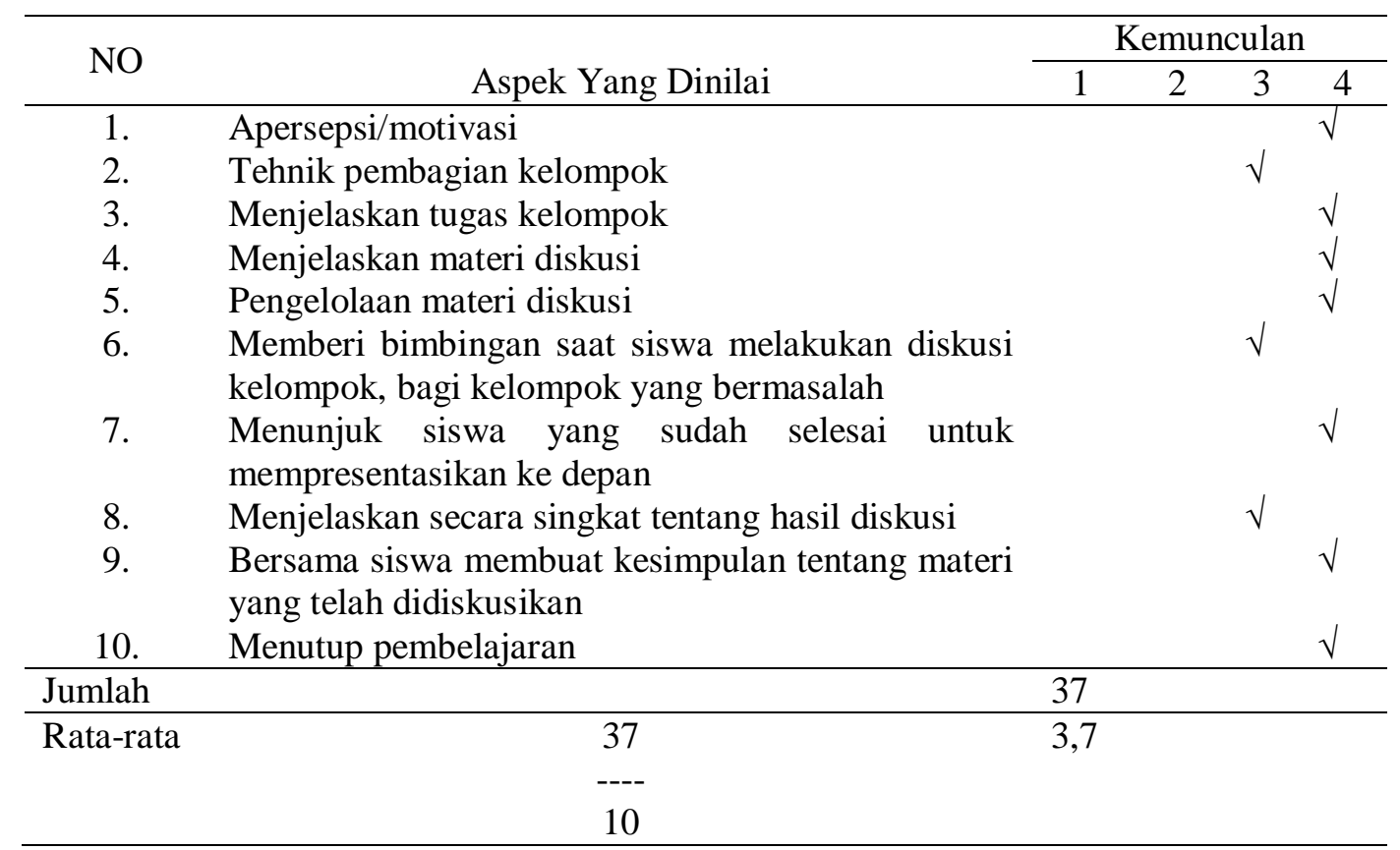

Keterangan :

1. Sangat tidak baik : 1 3. Cukup baik : 3

2. Kurang baik $: 2$ 4. Baik $: 4$

Guru membagikan LKS 3 dengan betul semua, adapun lembar kepada siswa untuk dipahami dan kerja siswa dapat dilhat pada tabel dikerjakan. Kemudian guru berkeliling 4.6.Hasil pengamatan guru mengajar memberikan bimbingan kepada dalam pembelajaran siklus satu kelompok yang menghadapi masalah. pertemuan ke 3 dapat dilahat pada Dan selanjutnaya guru melakukan evaliasi dari hasil kerja siswa yang dikerjakan melalui kelompok masingmasing, dan dari hasil kerja siswa sangat bagus karena hampir semua siswa mendapatkan nilai diatas 70, dan tabel 4.5

Dari skor pengamatan untuk guru pada pertemuan 3 siklus 1 diperoleh hasil 3, 7 (baik). Jadi siklus pertemuan 3 berlangsung dengan baik, karena guru dan juga peneliti telah malah banyak yang mengerjakan soal 


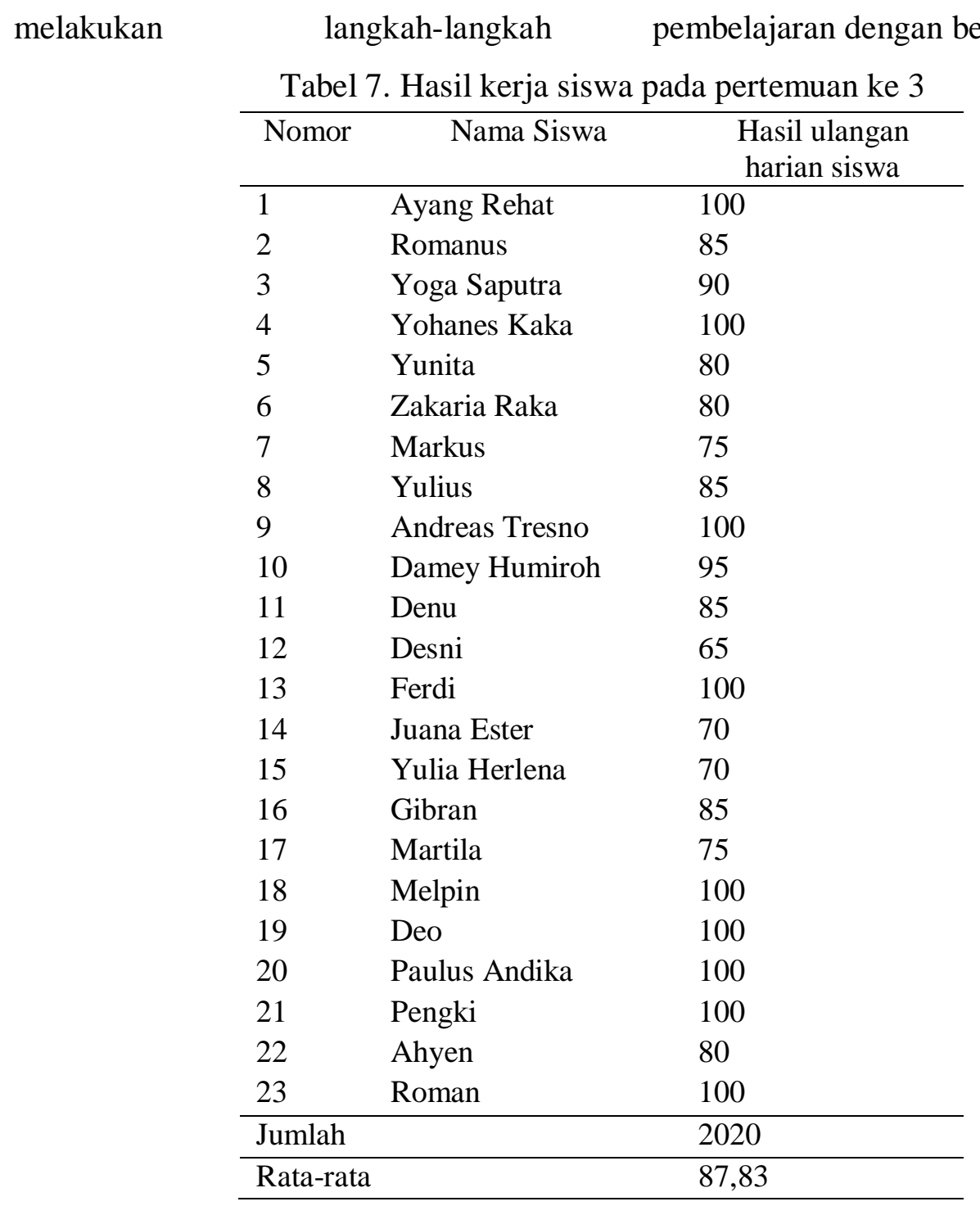

Skor rata-rata hasil belajar siswa pada pertemuan ke 3 sebesar 87,87 (sangat baik), karena sudah jauh diatas standar yang ditentukan peneliti yaitu $\geq 70$ dan prosentase ketuntasan siswa sebesar 95,7\%, sehingga pembelajaran berlangsung dengan baik. Kegiatan presentasi berlangsung baik, semua kelompok dapat menyelesaikan tugas kelompoknya tepat waktu.

Refleksi dilakukan setelah pelaksanaan siklus 1 berakhir, yaiitu pada pertemuan ke 3. Kesimpulan yang dapat diambil dari refleksi tersebut diantaranya adalah peneliti sudah dapat melaksanakan tahap-tahap pembelajaran dengan mengunakan media alam sekitar secara kelompok dengan baik, bimbingan tiap kelompok dilakukan secara merata, siswa sudah dengan baik bekerja berkelompok. Maka pembelajaran sudah dapat berjalan dengan lancar. Hal ini dapat dilihat pada nilai ketuntasan pada 
pertemuan 3 sudah mencapai indikator yang telah ditetapkan. Dengan demikian peneliti tidak perlu melanjutkan ke Siklus II, karena sudah dianggap berhasil.

Dari hasil observasi siswa terhadap pembelajaran dapat diketahui bahwa siswa merasa senang dengan pembelajaran yang dilakukan dengan pemberian kuis terlabih dahulu, serta siswa suka belajar berkelompok yang hasilnya dipresentasikan ke depan. Kegiatan tersebut akan memotivasi siswa untuk bertanya, menanggapi dan menghargai pendapat orang lain.

Berdasarkan tindakan yang telah dilakukan pada setiap petemuan maka dapat diketahuan proses hasil belajar yang telah dilakukan dalam pembelajaran pada siklus I pertemuan pertama, kedua dan ketiga dapat dilihat pada tabel berikut:

Tabel 8. Perbandingan Hasil Penelitian siklus I pada pertemuan I, II dan III

\begin{tabular}{lccc}
\hline No & Siklus I & $\begin{array}{c}\text { Nilai Rata- } \\
\text { rata siswa }\end{array}$ & $\begin{array}{c}\text { Hasil observasi } \\
\text { guru mengajar }\end{array}$ \\
\hline 1. & Pertemuan 1 & 61,30 & 2,20 \\
2. & Pertemuan II & 75,40 & 3,00 \\
2. & Pertemuan III & 87,83 & 3,75 \\
\hline
\end{tabular}

\section{SIMPULAN}

Penggunaan media alam sekitar secara langsung yang disertai dengan metode yang tepat pada pembelajaran struktur bagian tumbuh-tumbuhan dalam mata pelajaran IPA ternyata dapat meningkatkan hasil belajar siswa, memotivasi siswa untuk belajar, membantu siswa dalam diskusi, meningkatkan perhatian dan pemahaman siswa terhadap materi struktur tumbuh-tumbuhan. Terbukti dari nilai rata-rata yang diperoleh siswa sebesar 61,30 dan hasil observasi guru mengajar 2,20 pada siklus I pertemuan pertama, pada pertemuan ke dua nilai rata-rata siswa
75,40, hasil observasi guru mengajar 3.00, dan pada pertemuan ke tiga nilai rata-rata siswa 87,83 , hasil observasi guru mengajar 3,75,

Hasil penelitian yang telah dilakukan dapat dilihat dari pertemuan pertama sampai pertemuan ke tiga selalu mengalami kenaikan, dari pertemuan pertama ke pertemuan ke dua nilia rata-rata siswa mengalami kenaikan sebesra $23 \%$, hasil observasi mengajar guru sebesar 36\%, pertemuan ke dua ke pertemuan ke tiga nilai rata-rata siswa mencapai kenaikan $16.5 \%$, hasil observasi guru mengajar mencapai $25 \%$, tingkat keberhasilan pada pertemuan pertama sebesar 
$39,1 \%$, pada pertemuan kedua sebesar $68,9 \%$, dan pada pertemuan ke tiga sebesar $95,7 \%$.

Pembelajaran IPA pada materi struktur bagiuan tumbuh-tumbuhan dengan mengunakan media alam sekitar secara langsung dengan mengunakan langkah-langkah pembelajaran yang benar dapat meningkatkan hasil belajar siswa, terbukti dalam penelitian yang sudah peneliti lakukan dalam penelitian ini.

\section{REFERENSI}

Aryad, A. 2014. Media Pembelajaran. Jakarta: Rajagrafindo Persada.

Arikunto, S. 2010. Penelitian Tindakan Kelas. Jakarta: Rineka Cipta.

Dimyati dan Mujiono. 2006. Belajar dan Pembelajaran. Jakarta: Renike Cipta.

Nawawi, H. 2012. Metode PenelitianBidang Sosial. Yogyakarta: Gajah Mada University Press.

Depdiknas. 2007. Kurikulum Tingkat Satun Pendidikan SD/MI. Jakarta: Departemen Pendidikan Nasional.

Miarso. 2004. Menyemai Benih Teknologi Pendidikan. Jakarta: Pustekkom DIKNAS.
Sugiyono. 2008. Metode PenelitianKuantitatif Kualitatif $\& R \& D$. Bandung: Alfabeta.

Sujana, N. 2009. Penilaian Hasil Proses Belajar Mengajar. Bandung: Rosdakarya.

Sujana, N. 2015. Media Pengajaran; Bandung: Sinar Baru Algensindo.

Sukmadinata, Syaodih, Nana. 2010. Metode Penelitian Pendidikan, Bandung: Remaja Rosdakarya.

Trianto. 2010. Model Pembelajaran Terpadu.

Bandung: Grahasindo

Kartini. 2012. Upaya Meningkatkan Hasil Belajar IPA melalui Media Lingkungan Alam. Jurnal Penelitian 